\title{
The Effect of AEC in Shaping Entrepreneurial Motivation for Vocational High School Prospective Graduates
}

\author{
Kusumah Arif Prihatna'; Isanawikrama²; Adhi Bawono³ ${ }^{3}$ Edwin Joyo Hutomo ${ }^{4}$ \\ 1,2,3,4Binus Entrepreneurship Center, Bina Nusantara University \\ Jln. Kebon Jeruk Raya No. 27, Jakarta Barat 11530, Indonesia

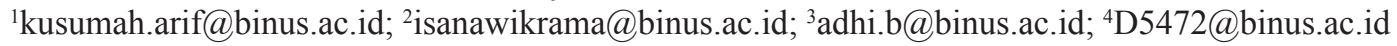

Received: $22^{\text {nd }}$ February 2017/ Revised: $30^{\text {th }}$ March 2017/ Accepted: $4^{\text {th }}$ April 2017

How to Cite: Prihatna, K. A., Isanawikrama, Bawono, A., \& Hutomo, E. J. (2017). The Effect of AEC in Shaping

Entrepreneurial Motivation for Vocational High School Prospective Graduates. Binus Business Review, 8(2), 85-90. http://dx.doi.org/10.21512/bbr.v8i2.2013

\begin{abstract}
This research aimed to investigate the factors forming the motivation of entrepreneurs based on the driving factors, namely the existence of a single market of ASEAN Economic Community (AEC). It was the assumption of the readiness of the students themselves. Basic theory used was the push and pull theory. Thus, with the driving factor, the research also aimed to see the interest factor from within. Respondents were prospective graduate students of Global Persada Vocational High School. Data were collected by distributing questionnaires processed by using quantitative research analysis and multiple linear regression. Partially, it is concluded that the formation of entrepreneurial motivation can be affected by factors of interest and it is not due to the push from outside concerning the unpreparedness of students in facing the single market of AEC.
\end{abstract}

Keywords: entrepreneurial motivation, push factor, pull factor, ASEAN Economic Community (AEC)

\section{INTRODUCTION}

ASEAN Economic Community (AEC) is the realization of a single market in Southeast Asia that has been done gradually. It started by ASEAN leaders meeting in Kuala Lumpur in 1992 (Setiawan, 2015). It has resulted in the agreement of ASEAN Vision 2020. Moreover, AEC single market is part of the implementation of the free market with the participating countries in ASEAN. The free market or free trade or trade liberalization is defined as a situation without tariff barriers or a situation with tariff reductions, and the situation of non-tariff barriers imposed on inflows and outflows goods and services. Thus, in a free market system, goods and services are exchanged between countries without restrictions and constraints of government intervention in the form of laws and regulations and quota restrictions. Moreover, the trade agreements are stipulated by the government (Fouda, 2012).

According to Bakhri (2016) and Aristeus (2014), AEC single market implementation in December 2015 aimed to improve the economic stability in the
ASEAN region and to compete with the economic movement of India and People's Republic of China (PRC). Moreover, Tedjasuksmana (2014) said that it was also to remove barriers to the economic activities implementation in the ASEAN region, where the economic activities were the trade of goods and services, the supply of skilled labor, and investment. The countries in ASEAN are Indonesia, Malaysia, Thailand, Philippines, Singapore, Brunei Darussalam, Vietnam, Laos, Myanmar/Burma, and Cambodia. It is used as a unified region market and production base. The formation of this single market allows the members of ASEAN to sell goods and services, invest, and find a job easily in other countries of Southeast Asia.

As the economists predict, AEC single market as a form of the free market can lead to positive or negative consequences for the economy in a single country. Gaston and Trefler (1997) said that the application of free market provided many positive effects, but it also highlighted the negative impacts on human rights in employment issues. The presence of the free market affects employment opportunities 
for the people of a single country. It is because the open competition has a direct impact on the workforce categorized as unskilled for certain businesses. According to Wood (1995), the emergence of a trade form has an impact on job seekers. The demand for unskilled workers would decrease in line with the need for skilled workforce. Thereby, it increases the inequality leading to unemployment.

Indonesia has a population of 250 million people which is $40 \%$ of the total share in ASEAN having the population of 625 million (Suroso, 2015). As described before, AEC single market can become two sides of the coin for Indonesia. It can be a good opportunity for Indonesia to flood the ASEAN market share with goods and services, but on the other hand, it is only used as a market share in the absence of the quality and quantity of products and human resources. This is due to a lack of readiness and ability to take advantage of a good momentum of the free market (Abdurofiq, 2014).

There are tremendous opportunities for job seekers since the market share becomes wide within the boundaries of state member. There is much availability of employment opportunities with the various needs of diverse skills. Related to the employment, AEC single market can also give opportunities for entrepreneurs to seek better employments in accordance with the desired criteria of the entrepreneurial business core. However, regarding education and productivity, it is thought that Indonesian workers are still unable to compete with Malaysia, Singapore, and Thailand (Abdurofiq, 2014). This issue may cause a very intense competition resulting in limited employment opportunities for Indonesian workers and can lead to weak economic for the community.

To overcome this issue, Indonesia can take steps by preparing skilled, intelligent, and competitive human resources. However, about the employment opportunity as part of jobs creation for workers, Indonesians could also take steps to create and develop more business opportunities and make entrepreneurship prosper.

In order to create and develop more business opportunities and make the entrepreneurship rise, the educational expertise and guidance on entrepreneurship can be applied nat the early age of the productive age. Therefore, it is not only about having the mindset of becoming skilled workers to find a job, but it is also creating employment opportunities in various forms of entrepreneurship in many fields to face AEC single market.

One of the ways done by developing skill in entrepreneurship is the education in vocational high school. The vocational high school has a unique character in producing graduates who are prepared to enter the world of employment. It also has a great opportunity to participate in developing the economy through entrepreneurship in various fields of specialization (Wibowo, 2011). Vocational students are given special education programs for those who have a common interest to develop certain skills. Those who gain the skills are ready to be an employee or entrepreneur according to the learned skill. Vocational students are part of the secondary level education which is in the early stages of productive age. It starts from the age of 15 years as described by Yuwono (2016). However, Vemmy (2012) stated there was a tendency that some vocational school graduates preferred to be an employee rather than an entrepreneur. Only a few of the graduates had an interest in entrepreneurship. Some of the issues led vocational students to have no interest in entrepreneurship after graduation. Those were fear of taking risks, fear of failure, no confidence, no capital, no motivation, and no desire to live independently (Wijaya, 2007).

Several researches have been conducted regarding entrepreneurial motivation. For example, Segal, Borgia, and Schoenfeld (2005) suggested that a motivation for entrepreneurship could be influenced by two factors. Those were driving factors from outside and the interest factor from inside (push and pull theory). Therefore, a proper condition that came from outside or from within could form the motivation for entrepreneurship. Widhardi and Suarta (2012) also supported two theories namely push theory and pull theory regarding entrepreneurial motivation. Push theory was a person who would start entrepreneurship due to the negative impulse such as dissatisfaction at work, the trouble of finding a job, or worries about work opportunities. Meanwhile, pull theory focused on a person who would start entrepreneurship due to the support and confidence that entrepreneurs could meet someone's expectations regarding the independence, prosperity, and success factors in entrepreneurship. According to Indarti and Rostiani (2008), pull theory can be considered as a positive factor that likely causes the intention of entrepreneurship, such as being able to see the opportunities, having an attitude of risk-taking, having creative ideas, and others.

Motivation is the psychological forces that determine the direction, intensity or level of effort, and the level of an individual perseverance in achieving objectives leading to a certain behavior (Astuti, 2014). Hanafi (2015) explained that motivation appeared due to individual efforts to meet the necessities of life. The basic of human needs that could motivate someone was in the first level of the hierarchy of needs. The basic human needs were air, food, drink, shelter, and others. Thus, it can be concluded that an individual had great chance to be motivated to overcome all the problems to achieve the fulfillment of his/her basic needs.

The other previous researches highlight more on entrepreneurial motivation. It is about the causes of internal intention and also supporting environment. However, it has never given any concerns related to negative impulses. The subject of this research focuses on the negative impulses that can lead to entrepreneurial motivation for vocational high school prospective graduates. The existence of a free market can have a negative impact, but it can also be a motivating factor for someone to start entrepreneurship. This research 
focuses on investigating the influence of driving factor from the outside and interest factor from the inside in accordance with push and pull theory. The results are expected to become an input for the development of learning framework in entrepreneurial education which is suitable for vocational high schools. In addition, it can produce graduates who choose to be entrepreneurs, create employment, and find ways to overcome the problems of the employment itself. It starts from the early of productive age in the era of the AEC single market. The problem used as a trigger is the existence of a free market, which is related to AEC single market. It may potentially hinder the vocational high school prospective graduates in achieving future needs.

There are three objectives in the research. First, it is to analyze the influence of external driving factors which is the emergence of a single market (AEC) on the future of vocational high school students which may form the deciding factor in motivation and decision to start entrepreneurship. Second, it is to see the influence of interest factors in vocational high school students which can be caused by the indirect talent causing the motivation to become entrepreneurs. Last, it is to find out the linkages between the external driving factors and the internal interest factors on the establishment of entrepreneurial motivation.

\section{METHODS}

The method is quantitative descriptive. It is based on a comparison of causation (ex post facto) (Kothari, 2004). This research is conducted on grade three students in Global Persada vocational high school with the total of 21 respondents. It is the combination of Computer Networking Technique and Multimedia major. The sampling technique is nonprobability sampling specifically saturated sampling. According to Sugiyono (2011), samples are taken with similar backgrounds. The backgrounds are grade three students of vocational education with information technology background, the tendency that the students use the opportunity provided by the school to utilize existing facilities regarding their business interests, and the students' age is 17-18 year old. According to Winkel (1997), it is an initial stage of reproductive age and transition to the employment which students are encouraged to integrate insights that might affect the rise toward a certain interest.

This research is conducted by using primary data by giving questionnaires directly to the respondents. The questionnaires are analyzed by using Likert scale. It is a declarative statement followed by choice of options indicating various degrees of agreement on a statement. It also describes opinions, beliefs and attitudes of the subject studied (Amir, 2015). The responses to the questionnaire using Likert scale consists of fivescales. It has score 5 to 1 for a positive statement, namely "strongly agree", "agree", "neutral", "disagree", and "strongly disagree". For the secondary data, it is obtained from the literature review in the form of books, journals, and previous studies. The research model is shown in Figure 1.

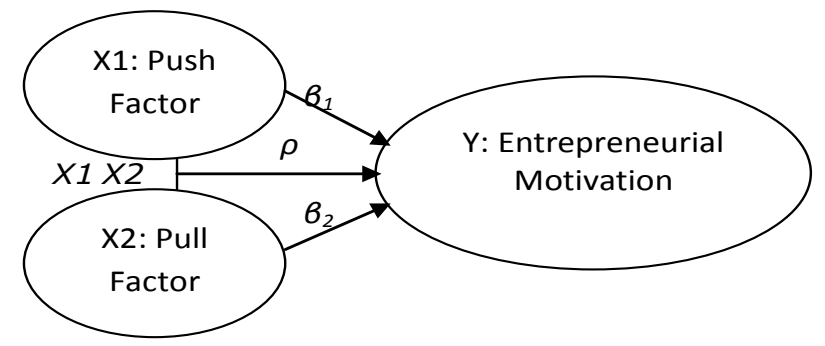

Figure 1 Research Model

The research variables based on the model are divided into three. First, push factor (X1) is the encouragement to entrepreneurship based on indicators such as knowledge and skills, competition, employment opportunities, availability of jobs, foreign workers, and income. Second, pull factor (X2) is the interest in entrepreneurship based on indicators like social prestige, personal challenge, creativity, opportunity, leadership, and flexibility. Three, entrepreneurial motivation (Y) is the formation of motivation including chance, choice, success, motivation factor, income, and freedom.

Then, the validity and reliability of data obtained are tested using Pearson product-moment correlation, and Cronbach's alpha respectively. It finds out the accuracy or precision of an instrument measuring what should be measured. It also finds the consistency of an indicator or a variable of the instrument. After instrument test has been done, the data are tested using classical assumption test with the purpose of inference or prediction. It consists of normality test, heteroscedasticity test, multicollinearity test, autocorrelation test, and linearity test.

In addition, the tested data are analyzed using multiple linear regression to reach the equation and the hypothesis for the conclusion. The data analyzer tool to test the data and to obtain the conclusion is IBM SPSS Statistic 23.

\section{RESULTS AND DISCUSSIONS}

The results of validity test using Pearson product-moment correlation are in Table 1 . This refers to the distribution of value r-table of 5\% significance with $\mathrm{N}=21$ or 0,433 by Yudiaatmaja (2013). The results show that validity in the statement of values of r-count is higher than r-table. Thus, it can be stated that all the indicators in the questionnaires are valid and can be used as the research instrument.

The results of reliability test using Cronbach's alpha are in Table 2. Reliability test shows that all three research instruments namely push factor, pull factor, and entrepreneurial motivation have higher coefficient of Cronbach's alpha than 0,6 (Ghozali, 2005). On the other words, all the instruments are reliable and can be used in conducting the research. 
Table 1 Result of Validity Test

\begin{tabular}{llc}
\hline Variable & Items & r-count \\
\hline Push Factor (X1) & X1.1 & 0,739 \\
X1.2 & 0,688 \\
& X1.3 & 0,732 \\
X1.4 & 0,578 \\
& X1.5 & 0,481 \\
X1.6 & 0,642 \\
Pull Factor (X2) & X2.1 & 0,740 \\
& X2.2 & 0,711 \\
& X2.3 & 0,801 \\
& X2.4 & 0,824 \\
X2.5 & 0,452 \\
Entrepreneurial Motivation (Y) & X2.6 & 0,5 \\
& Y1 & 0,756 \\
& Y2 & 0,812 \\
& Y3 & 0,788 \\
& Y4 & 0,524 \\
& Y5 & 0,669 \\
& Y6 & 0,677 \\
\hline
\end{tabular}

Table 2 Result of Reliability Test

\begin{tabular}{lc}
\hline \multicolumn{1}{c}{ Variable } & Cronbach's Alpha \\
\hline Push Factor (X1) & 0,716 \\
Pull Factor (X2) & 0,763 \\
Entrepreneurial Motivation (Y) & 0,795 \\
\hline
\end{tabular}

Data analysis technique uses multiple linear regressions. It is in equation (1).

$$
Y=a+b_{1} X_{1}+b_{2} X_{2}
$$

Where $\mathrm{Y}$ is the dependent variable representing the entrepreneurship motivation. X1 is a push factor, and $\mathrm{X} 2$ is a pull factor. $\mathrm{a}$ is a constant, while $\mathrm{b}_{1}$ and $b_{2}$ are regression coefficients of independent variables (Kasmadi \& Sunariah, 2014).

Normality test uses Shapiro-Wilkparameter because the sample is lower than 50 . Normality test shows that the significance of three variables is higher than 0,05. According to Santoso (2000), the regression model has normal distribution. The result can be seen in Table 3.

Table 3 Normality Test

\begin{tabular}{lc}
\hline \multicolumn{1}{c}{ Variable } & Significant Value \\
\hline Push Factor (X1) & 0,147 \\
Pull Factor (X2) & 0,118 \\
Entrepreneurial Motivation (Y) & 0,216 \\
\hline
\end{tabular}

Heteroscedasticity test is conducted with Glejser test. Heteroscedasticity test shows that the significance of the two independent variables is higher than 0,05 . It means that there is no heteroscedasticity in the regression model (Alhusin, 2003). The result is in Table 4.

Table 4 Heteroscedasticity Test

\begin{tabular}{lc}
\hline \multicolumn{1}{c}{ Variable } & Significant Value \\
\hline Push Factor (X1) & 0,853 \\
Pull Factor (X2) & 0,719 \\
\hline
\end{tabular}

Multicollinearity test is measured by the value of tolerance and Variance Inflation Factor (VIF). Multicollinearity test shows that the tolerance value of two independent variables is higher than 0,1 . Meanwhile, VIF of two independent variables is lower than 10. According to Priyatno (2008), it indicates that there is no multicollinearity in the regression model. The result is shown in Table 5.

Table 5 Multicollinearity Test

\begin{tabular}{lcc}
\hline \multicolumn{1}{c}{ Variable } & Tolerance & VIF \\
\hline Push Factor (X1) & 0,673 & 1,487 \\
Pull Factor (X2) & 0,673 & 1,487 \\
\hline
\end{tabular}

Autocorrelation test performed using DurbinWatson method. The calculation value of the three variables obtained is 2,166 . With the $5 \%$ of significance and $\mathrm{N}=21$ in line with the number of respondents and the number of dependent variables $(k=2)$, the value from the tabel Durbin Watson (DW) is 1,5385. The value from the table which is 1,5385 is lower than the value obtained which equals to 2,166 . Then, the value obtained $(2,166)$ is lower than $2,4615(4-1,5385$ $=2,4615)$ (Priyatno, 2013). From the calculation and comparison, it can be concluded that there is no autocorrelation in regression model.

Moreover, linearity test is done with significance level of 0,05 . The results show that the value of linearity is 0,016 . The value of 0,016 is lower than 0,05 . Thus, it can be stated that the linear regression equation models are having linearity between the variables. Based on the model equation, it is necessary to find the relationship between the independent variables individually or simultaneously on the dependent variable (Siregar, 2015a).

The hypotheses tested are (1) students' entrepreneurial intentions are caused by the emergence of AEC single market, and (2) students' entrepreneurial intentions are because of the intention to start a business. Thus, it forms entrepreneurial motivation for vocational high school prospective graduates. The hypotheses are as follows.

Ho: push or pull factor simultaneously $(\rho)$ or partially $(\beta)$ has no significant effect on entrepreneurial motivation.

Ha: push or pull factor simultaneously $(\rho)$ or partially $(\beta)$ has significant effect on entrepreneurial motivation. 
Table 6 Multiple Linear Regression Analysis

\begin{tabular}{lccc}
\hline Variable & Regression coefficients & t count & Sig. \\
\hline Constants & 3,424 & 1,036 & 0,314 \\
X1 & 0,149 & 0,929 & 0,365 \\
X2 & 0,738 & 5 & 0 \\
f count $=$ & 23,178 & & \\
$\mathrm{R} 2=$ & 0,72 & & \\
\hline
\end{tabular}

Regression model that can be written from the calculation in the form of regression equation is in equation (2).

$$
Y=3,424+0,149 X_{1}+0,738 X_{2}
$$

These variables have a regression coefficient with a positive direction. The increase in entrepreneurial intentions caused by push and pull factor increase the motivation of vocational high school prospective graduates on entrepreneurship. From the result of the calculation, f-count is 23,178 . Moreover, f-count of 23,178 is higher than 3,55 which is taken from the value based on the f-table (Siregar, 2015b). Thus, $\mathrm{Ho}$ is rejected, and $\mathrm{Ha}$ is accepted. This suggests that there are significant effects of push and pull factor simultaneously in motivating vocational high school prospective graduates on entrepreneurship.

For the t-count of the push factor, the value obtained is 0,929 . Thus, $t$-count of push factor $(0,929)$ is lower than 1,73406 which is taken from the value based on the t-table (Siregar, 2015b). Thus, Ho is accepted, and $\mathrm{Ha}$ is rejected. There is no influence of push factor on the entrepreneurial motivation for vocational high school prospective graduates.

Moreover, t-count of the pull factor obtained is 5. Then, t-count of pull factor (5) is higher than 1,73406 which is taken from the value based on the t-table (Siregar, 2015b). Therefore, Ho is rejected, and $\mathrm{Ha}$ is accepted. There is the influence of pull factor on the entrepreneurial motivation for vocational high school prospective graduates.

Based on the coefficient of determination calculation in Table 6, it can be seen that the value of $\mathrm{R}^{2}$ is $0,72(72 \%)$. It shows that the influence percentage of push factor and pull factor on the entrepreneurial motivation is $72 \%$ (Siregar, 2015b). It is clear that the variation of independent variables used in the linear regression model is only $72 \%$ on the dependent variable. Meanwhile, there are $28 \%$ of influence that cannot be explained, so it is not included in the research model.

\section{CONCLUSIONS}

There are several conclusion based on the obtained results. First, push factor is assumed to encourage vocational high school prospective graduates on entrepreneurship characterized by the existence of the AEC single market. It is not proven to provide a significant influence on the formation of the student's entrepreneurial motivation. Second, pull factor is the interest of one self that causes intention of entrepreneurship within vocational high school prospective graduates. It has a significant effect on the formation of their entrepreneurial motivation. Third, Simultaneously push and pull factor contributes about $72 \%$ to the formation of vocational high school prospective graduates' entrepreneurial motivation.

There are limitations and implications in this research. First, the research is conducted only on vocational students whose education is directed at a specific vocational skill in the field. It is better to make a comparison with high school students to obtain a complete picture of the attitudes of students with the same age on the effect of the AEC single market. Second, the results show there are $28 \%$ of the unknown factors that can affect the formation of students'entrepreneurial motivation. Therefore, it is better to conduct further research to determine certain single independent variable on the dependent variable separately. It is to explore the possibility of forming vocational high school prospective graduates' entrepreneurial motivation.

\section{REFERENCES}

Abdurofiq, A. (2014). Menakar pengaruh masyarakat ekonomi ASEAN 2015 terhadap pembangunan Indonesia. SALAM: Jurnal Sosial dan Budaya Syar-i, 1(2), 249-256. https://doi.org/10.15408/sjsbs. v1i2.1543

Alhusin, S. (2003). Aplikasi statistik praktis dengan menggunakan SPSS 10 for Windows ( $2^{\text {nd }}$ ed.). Yogyakarta: Graha Ilmu.

Amir, M. T. (2015). Merancang kuesioner: Konsep dan panduan untuk penelitian sikap, kepribadian, dan perilaku ( $1^{\text {st }}$ ed.). Jakarta: Prenadamedia Group.

Aristeus, S. (2014). Peluang industri dan perdagangan indonesia dalam pelaksanaan masyarakat ekonomi ASEAN. Jurnal Rechtsvinding, 3(2), 145-162.

Astuti, R. D. (2014). Pengantar bisnis (13 ${ }^{\text {th }}$ ed.). Pamulang: Universitas Terbuka.

Bakhri, B. S. (2016). Masyarakat Ekonomi ASEAN (MEA) dan tinjauan dari perspektif ekonomi Syariah. Jurnal Ekonomi, Manajemen dan Akutansi I, 25(2), 63-74.

Fouda, R. A. N. (2012). Protectionism and free trade: A country's glory or doom? International Journal of Trade, Economics and Finance, 3(5), 351-355.

Gaston, N., \& Trefler, D. (1997). The labour market consequences of the Canada-US Free Trade Agreement. Canadian Journal of Economics, 30(1), $18-41$.

Ghozali, I. (2005). Aplikasi analisis multivariate dengan program SPSS. Semarang: Universitas Diponegoro.

Hanafi, M. M. (2015). Manajemen keuangan. Yogyakarta: BPFE Yogyakarta.

Indarti, N., \& Rostiani, R. (2008). Intensi kewirausahaan mahasiswa: Studi perbandingan antara Indonesia, Jepang dan Norwegia. Jurnal Ekonomika dan Bisnis Indonesia, 23(4), 1-27. 
Kasmadi, \& Sunariah, N. S. (2014). Panduan modern penelitian kuantitatif ( $2^{\text {nd }}$ ed.). Bandung: Alfabeta.

Kothari, C. R. (2004). Research methodology: Methods \& techniques ( $2^{\text {nd }}$ ed.). New Delhi: New Age International Publisher.

Priyatno, D. (2008). Mandiri belajar SPSS (3 ${ }^{\text {rd }}$ ed.). Yogyakarta: Media Kom.

Priyatno, D. (2013). Mandiri belajar analisis data dengan SPSS. Yogyakarta: Media Kom.

Santoso, S. (2000). Buku latihan SPSS statistik parametrik ( $1^{\text {st }}$ ed.). Jakarta: PT. Elek Media Komputindo.

Segal, G., Borgia, D., \& Schoenfeld, J. (2005). The motivation to become an entrepreneur. International Journal of Entrepreneurial Behavior \& Research, 11(1), 42-57. https://doi.org/10.1108/13552550510580834

Setiawan, R. I. (2015). Persepsi tenaga kerja lokal pada invasi tenaga kerja asing di Indonesia: Tantangan menghadapi Masyarakat Ekonomi ASEAN (MEA) Tahun 2015. Jurnal Kompilek (Kompilasi Ilmu Ekonomi), 7(2), 202-218.

Siregar, S. (2015a). Metode penelitian kuantitatif ( $1^{\text {st }}$ ed.). Jakarta: Prenadamedia Group.

Siregar, S. (2015b). Statistika terapan untuk perguruan tinggi ( $1^{\text {st }}$ ed.). Jakarta: Kencana.

Sugiyono. (2011). Metode penelitian pendidikan (Pendekatan kuantitatif, kualitatif, dan $R \& D)$. Bandung: Alfabeta.

Suroso, G. T. (2015). Masyarakat Ekonomi ASEAN dan perekonomian Indonesia. Retrieved from http:// www.bppk.kemenkeu.go.id/publikasi/artikel/150artikel-keuangan-umum/20545-masyarakatekonomi-asean-mea-dan-perekonomian-indonesia
Tedjasuksmana, B. (2014). Potret UMKM Indonesia menghadapi Masyarakat Ekonomi ASEAN 2015. In The $7^{\text {th }}$ NCFB and Doctoral Colloquium 2014.

Vemmy, C. (2012). Faktor-faktor yang mempengaruhi intensi berwirausaha siswa SMK. Jurnal Pendidikan Vokasi, 2(1), 117-126. https://doi.org/10.1007/9781-4419-0443-3

Wibowo, M. (2011). Pembelajaran kewirausahaan dan minat wirausaha lulusan SMK. Eksplanasi, 6(2), 109-122.

Widhardi, C. I. S., \& Suarta, I. K. (2012). Analisis faktor-faktor yang memotivasi mahasiswa berkeinginan menjadi wirausaha. Jurnal Bisnis dan Kewirausahaan, 8(1), 54-63.

Wijaya, T. (2007). Hubungan adversity intelligence dengan intensi berwirausaha (Studi empiris pada siswa SMKN 7 Yogyakarta). Jurnal Manajemen dan Kewirausahaan, 9(2), 117-127. https://doi. org/10.1007/978-1-1411-1-1438

Winkel, W. S. (1997). Bimbingan dan konseling di institusi pendidikan. Jakarta: Grasindo.

Wood, A. (1995). How trade hurt unskilled workers. The Journal of Economic Perpective, 9(3), 57-80.

Yudiaatmaja, F. (2013). Analisis regresi dengan menggunakan aplikasi komputer statistik SPSS ( $1^{\text {st }}$ ed.). Jakarta: Gramedia Pustaka Utama.

Yuwono, S. (2016). Keragaman sumberdaya insani sebagai potensi meningkatkan kesejahteraan karyawan. In Seminar Asean Psikologi dan Kemanusiaan II: Optimalisasi Kekuatan Insaani untuk Produktivitas dan kesejahteraan. 